"Challenges impacting on small independent retailers performance in Soweto, Johannesburg in South Africa"

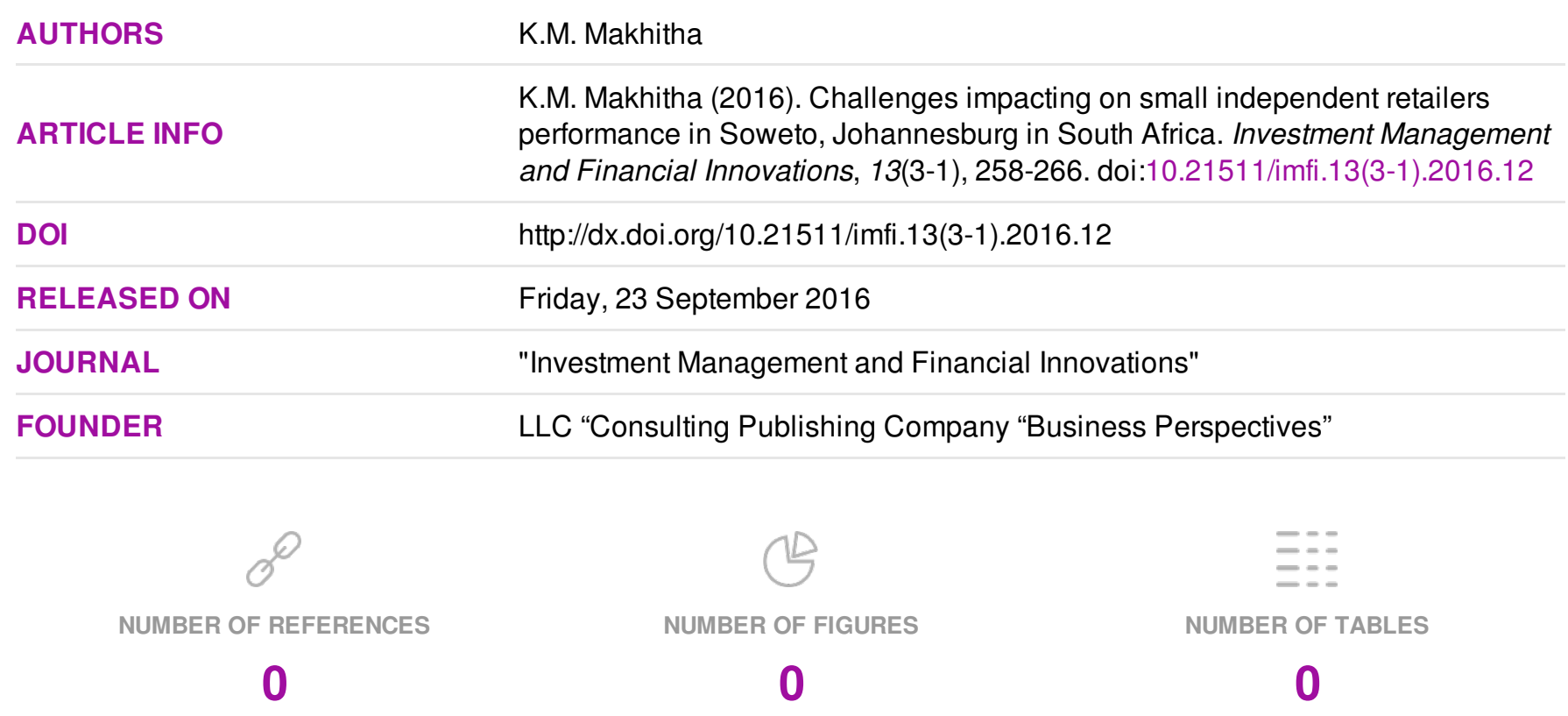

C The author(s) 2022. This publication is an open access article. 


\title{
Challenges impacting on small independent retailers performance in Soweto, Johannesburg in South Africa
}

\begin{abstract}
This study investigated the challenges independent retailers in Soweto, Johannesburg in South Africa face. The empirical research using a survey method was conducted among independent retailers selling different types of goods. Due to inaccessibility of a database on independent retailers in SA, a convenience sampling method was adopted for the study. Existing literature was used to design a questionnaire targeted at independent retailers to investigate the challenges that impact on their business performance. The findings of the study revealed that competition is the major challenge that independent retailers face which is supported by existing research findings. Other challenges included costs of buying the products, high inventory costs and high rental costs. Furthermore, this study found that marketing related challenges are major challenges compared to finance related challenges. Independent retailers need to market the businesses appropriately in order to survive and do better than their competitors.
\end{abstract}

Keywords: independent retailess, costs, buying, selling, goods.

JEL Classification: L81, F1.

\section{Introduction}

Independent retailers in South Africa (SA) fall into the DTIs definitions of small, medium, and micro Enterprises (SMMEs), as outlined by the National Strategy for Small Business Development (DTI, 1996, p. 6). The small medium and micro enterprises (SMMEs) are generally referred to as the SMEs globally. However, in this study, they will be referred to as the SMEs. The small and medium businesses (SMEs) play a vital role in the economic development of a country (Muhammed, Char, Yasoa \& Hassan, 2010). SMEs fulfill a number of roles ranging from poverty alleviation and employment creation to international competitiveness (Nieman, Hough \& Nieuwenhuizen, 2003). SMEs have become a critical solution for starting and developing the standard of living in the South Africa owing to the low economic growth, high unemployment and an unsatisfactory level of poverty in South Africa, particularly in the rural areas (Lekhanya, 2010). SMEs are usually defined in terms of employment or turnover that they generate. SMEs are defined as firms with fewer than 250 employees or annual turnover of approximately R 300 million. Over $90 \%$ of all firms (including listed companies) in South Africa are being classified as SMEs. It is, therefore, accepted that SA businesses with annual turnover of less than R 50 million should be classed as SMEs (Blueprint Strategy \& Policy, 2005).

The SA economy is dominated by small, medium and micro firms (Sawers et al., 2008, p. 173) which are, to a very large extent, associated with economic empowerment, job creation and employment within

(C) K.M. Makhitha, 2016.

K.M. Makhitha, Department of Marketing and Retail Management, University of South Africa (Unisa), South Africa. disadvantaged communities (Davies, 2001, p. 4). According to Kongolo (2010), SMEs account for almost $91 \%$ of businesses and contribute $60 \%$ towards the country's employment and $51 \%$ to $57 \%$ towards the Gross Domestic Product (GDP).

Independent retailers are privately owned businesses that do not belong to a larger chain (W\&R Seta, 2011). They are increasingly losing customers to major retailers in SA, since customers are spending less in independent stores compared to large retailers (Durhum, 2011). The major retailers are increasingly penetrating into townships, peri-urban and rural areas have affected small, informal and independent retailers, leading to a decrease of these retailers, with some of these retailers experiencing decline in profitability (Department of Economic development, 2015). The informal and independent portion of this category was estimated at R73.9 billion in 2010 and is forecasted to grow by $45 \%$ to R115.6 billion in 2013. A staggering $22.5 \%$ of total consumer spends on food and groceries are done at informal or independent retailers, who service $81 \%$ of households in South Africa (Fernridge and Bank of America Merril Lynch, 2011). It is, therefore, important to investigate challenges that small independent retailers in SA are facing that impact on their performance.

\section{Independent retailers in South Africa}

The SA retail market is largely dominated by a small number of major retail and consumer goods companies. The four largest retailers in the country are Shoprite, Pick ' $\mathrm{n}$ Pay, Spar, Woolworths and Massmart and constitute a combined 60\% market share. Shoprite is the biggest grocery retailer by market share (PWC, 2012). Major retailers in SA have increased their market penetration and have also increased marketing efforts through brand promotion and advertising (Durham, 2011). 
Independent retailers are privately owned businesses that do not belong to a larger chain (W\&R Seta, 2011). They are small businesses targeting lower living standard measure (LSM) customers in periurban, township, industrial and central areas of the city. They include food and non-food retailers such as cash and carry's that have both wholesale and supermarket offering. They also include the spaza shops, spazarettes and superettes. There are over 100000 informal stores in SA. They stock fast moving items and operate at very low profit margins (das Nair \& Dube, 2015). Independent retailers emerged as a result of the colonization that demarcated shopping and residential zones for minority citizens and black majority citizens. This created opportunities for black entrepreneurs to establish businesses to serve their communities (Chikwekwe, 2015).

It has been estimated that the modern retail industry accounts for approximately $70 \%$ of national retail markets, and within this, supermarkets are an important source of supply in the retail food sector (Standard Bank, 2014). This has created challenges for small independent retailers (both formal independent supermarkets and 'spaza' shops), although it appears that this trend may be changing as independent retailers find alternative methods to benefit from economies of scale. Independent retailers, therefore, need to identify and overcome challenges that inhibit them from competing against the major retailers successfully.

The SA retail sector is composed of the formal and informal sector. The informal sector consists mainly of spaza shops, hawkers and street vendors, which are found in townships. They are served mainly by the wholesale market. The food and groceries market constitute $22 \%$ of the informal or independent retailers, which supply $81 \%$ of households in SA. The informal and independent retail market grew 45\% from R79.5 billion in 2010 to an estimated R115.6 billion in 2013 (Sustainalytics, 2012; W\&R Seta, 2011).

\section{Independent retailers and challenges}

Independent retailers face many challenges that impact on their growth and survival. Existing government initiatives have fallen short, in some instances, to support small businesses. It is important that challenges facing independent retailers be identified, so that solutions to these challenges may be sought for businesses and policymakers. Existing studies have sought to identify challenges impacting on SMEs, but this has not led to permanent solutions to the problems. One of the major challenges of SMEs is that they size and that they are owner managed. This implies that the owner-managers are responsible for all business activities involving managing the business, purchasing, production, human resources, sales and marketing, financial management and so forth, which impact on their ability to perform these function successfully (Horgath-Scott, Watson \& Wilson, 1996).

Several studies listed different factors impacting on SMEs. A study by Radipere \& Van Scheers (2005) found that SMEs face challenges such as marketing of products, locality, and lack of knowledge of the market. Further to these findings, Van Scheers (2011) stated that SMEs face challenges with marketing of their products, lack of understanding the market and cannot perform market need analysis. They are unable to segment the market and cannot successfully and effectively market their products (Van Scheers, 2011).

Lekhanya (2010) also found marketing to be a major challenge for SMEs, since the study identified lack marketing knowledge and expertise and limited use of marketing strategies as major challenges. However, Huang and Brown (in Simpson \& Taylor, 2002) posited different factors, although marketing was still considered a major challenged. Additional factors identified were human resources, general management and production and operations.

In addition to marketing related factors, Lewis (2005) pointed to supply chain inefficiency as one of the most prevalent issues facing SMEs. Thakkar et al., (2008), reiterated that SMEs face severe pressure to produce the "best" product, at the cheapest price, and with the shortest manufacturing lead time. Furthermore, Rogerson (2001) pointed lack of access to finance as a major limitation for small enterprises affecting their survival (Rogerson, 2001; Migiro \& Ochola, 2005, p. 292). According to Chiliya, Herbst \& Roberts-Lombard (2009), SMEs fail to embark on extensive marketing practices due to lack of finance.

Additional factors affecting SMEs are inability of SMEs to prepare a business plan, ineffective in acquiring and retaining of employees, capital inadequacy and lack of access to commercial land which increases cost of doing business. Furthermore, SMEs lack time, resources, technology or expertise to research and develop new business ideas and innovations, lack the business experience needed to drive the performance of their businesses. SMEs also lack of necessary education and training; and face challenges such asinsufficient finance and bargaining power; finance costs; limited or no access to markets and poor products demand; trade regulations; and improper infrastructure (Hyder \& Lussier, 2016, Chiliya \& Robrets-Lombard, 2012; Cant \& Lightelm, 2003). 
Challenges faced by independent retailers are not unique from those of other SMEs. However, it is important to outline specific challenges as laid out in literature that specifically affect independent retailers. Das Nair and Dube (2015) identified a number of challenges that independent retailers in SA are facing. This included access to finance, lack of business management skills and lack of retail capabilities. Factors such as the regulatory barriers (zoning, packaging and labeling, health and safety requirements, etc.) were regarded as minor challenges for independent retailers. Since the majority of independent retailers trade in grocery related items, they compete directly with supermarkets. These supermarkets offer the supplementary service of arranging a wide assortment of other, non-food, products selling concurrently in a convenient setting and location with a focus on quality, service, 'onestop' shopping and an overall shopping experience (Basker \& Noel, 2013) that some independent retailers do not, thus, create a competitive disadvantage. Supermarkets also invest in logistics, distribution centres, networks and inventory maintenance more than independent retailers (das Nair \& Dube, 2015).

\section{Independent retailers and business performance}

The GEM report (2008) has reported that SMEs in SA do not have a life span of more than 5 years. Brink and Cant (2009) further estimated the overall failure rate of SMEs in SA at $70 \%$ to $80 \%$. There is no universal definition of success; however, profits, turnover and financial assets have been associated with a business success (McCarton-Quinn \& Carson, 2003, p. 207).

Due to lack of access to finance that limit SMEs ability to market their businesses, SMES fail to aquire new customers which limit their growth (Chiliya et al., 2009). The growth of SME is associated with a successful product-market strategy; how managers create and exploit market opportunities and cope with difficulties and a greater propensity to follow a strategy of focused differentiation and a lower propensity to compete on price (Horgath-Scott, Watson \& Wilson, 1996). Marketing has been cited by researchers as having impact on the survival and growth a SMEs (Gbolagade, Adesola \& Oyewale, 2013, p. 65; Hassan, Qureshi, Sharif \& Mukhtar, 2013, p. 264; Van Scheers, 2011).

To ensure that they are buying the right product at the right time and the right price and right quantity, businesses select suppliers from whom they will purchase goods and services. This is because supplier selection impact on the performance of a business since what the business buy, especially raw materials impact on the quality of products that they will produce (Bhutta \& Hug, 2002, p. 126). Supplier selection is the evaluation of supplier capabilities and performance compared to other similar companies with the purpose to improve the buying business performance. It has become more relevant for buying businesses since it determines their performance (Kannan \& Tan, 2002, p. 1). Ebrahimpour and Johnson (1992) found a positive association between the use of non-price factors in supplier selection and perceived organizational performance.

Supplier selection has a direct effect on their economic and financial performance. To improve results, particular attention must be given to the purchase of products and their associated services. Supplier accessibility facilitates access to the retailer as far as this accessibility will guarantee supplier capacities (Abbad \& Paché, 2013).

According to Naude (2014), the distance between the buyers and their suppliers can have an impact on the timeous delivery of goods, transportation and logistical costs, flexibility with regard to the frequency of deliveries, and service levels. Small businesses may also benefit economically buying from local suppliers (Leenders et al., 2006, p. 272). Businesses can gain competitive advantages through choosing the right supplier (Agarwal, Sahia, Mishra, Bag \& Singh, 2011, p. 801). Retail buyers emphasize rational criteria (financial, marketing and logistical criteria) that have a direct impact on the large food retailer's financial results (Abbad \& Paché, 2013).

\section{Problem statement}

The SA retail market is the biggest retail market in Africa and was rated the $24^{\text {th }}$ on A.T. Kearney's 2010 Global Retail Development Index (GRDI) Africa due to wide array of shopping mall and retail development (Thomas White, 2011). The burgeoning of new shopping malls across the country, especially those opening in previously disadvantage areas has brough about challenges to small independent retailers who must find ways to compete against these large retailers and survive. The independent retailers owned by SA blacks are also under competitive pressure from those owned by foreigners who operate in cities, townships and rural areas. These foreign owned retailers sell products cheaper and use price discounting as a strategy to capture the market from existing stores. The SA owned retailers are survivalist micro enterprises, while the foreign owned ones are big enough to be considered formal businesses (Liedman, Charman, Piper \& Peterson, 2013).

Like other developing countries, there are various barriers that inhibit the growing of independent retailers. Various sources of literature have identified key variables that inhibit the growth and survival of independent retailers. These are linked to business management skills, human resources, unavailability of suppliers, finance and marketing. This research purport to determine challenges that impact on the growth of independent retailers in SA. 
Soweto was incorporated into the Greater Johannesburg Metropolitan area in 2001. Shopping centre developments have taken place in Soweto, including one regional shopping, Maponya Mall. Such development is part of 2005 Soweto Retail Strategy, a Soweto Development Initiative and the Township Development Program for Soweto in 2002. The development of shopping malls in Soweto and other townships created challenges for small businesses in the area, since these small independent retailers have to compete with large retail chains.

\section{Objectives of the study}

The purpose of this study is:

- To identify the challenges facing independent retailers in SA.

- To determine the types of challenges and the impact they have on independent retailers in SA.

\section{Research methodology}

The study targeted small independent retailers in Soweto and Johannesburg city centres in Johannesburg, SA. Johannesburg is the largest city in SA. Soweto is the largest township in Johannesburg and is an amalgamation of several different townships. Over 43 per cent of the population of the City of Johannesburg lived in Soweto in 2004 (Ligthelm, 2008).

A convenience sampling method was adopted owing to lack of access to a database of independent retailers in Johannesburg, SA. Convenience sampling is a sampling method that allows a researcher to choose whoever is available at a lower cost (Cooper \& Schindler, 2006, p. 245). The study targeted formal, independent retailers situated in Soweto and Johannesburg and included retailers in different locations within the targeted areas. The sample excluded branches of large retail stores, franchises and informal retailers such as spaza shops, street vendors and those selling and providing services. Interviews were conducted with the owners or managers of the businesses, since the measurement of entrepreneurial ability to compete and survive forms is an important element of this study.

Data were collected using two fieldworkers who were trained prior to data collection. The questionnaire was pre-tested with 20 independent retailers. Feedback from the pilot test was used to adapt the wording of the questionnaire. The questionnaire was of selfcompletion nature, fieldworkers distributed the questionnaires to independent retailers who were responsible for completing the questionnaire. Over 200 questionnaires were distributed; however, only 104 of them were completed, yielding a $52 \%$ response rate. This was due to the lack of willingness from independent retailers to participate in the study. The questionnaire was designed using information collected from literature. There were 23 yes' or 'no' dichotomous questions on challenges impacting on independent retailers that were listed on the questionnaire. Respondents were given an opportunity to add more challenges and adding the item 'otherplease specify' on the questionnaire. There were 11 demographic questions listed on the questionnaire.

Data was analyzed using SPSS version 23. Descriptive statistics were conducted and the results are reported and discussed in the next section. The frequencies and percentages of the challenges were determined during statistical analysis. Descriptive statistics were used to identify the challenges placing more pressure on independent retailers and was also useful in grouping the challenges to determine if they were finance related, marketing related, supplier related or business related.

\section{Results and discussion}

\section{Descriptive statistics}

Majority of respondents were males, constituting about 60 percent of the population $(\mathrm{N}=61)$. Most of the respondents fall in the 30-40 age categories, as shown by 30.4 percent of the respondents $(\mathrm{N}=31)$ followed by those between 41-50 age categories with 29.4 percent $(\mathrm{N}=30)$ of the population. It seems as though independent retailers are owned by older people than by younger ones in SA. The respondents consist mainly of those who have completed Grade 12/matric, represented by 51 percent of the population $(\mathrm{N}=52)$ followed by those with a diploma or certificate (27.5, $\mathrm{N}=28$ ) percent.

Most of the retailers have been in operation for between 1 and 3 years, as shown by 38.2 percent $(\mathrm{N}=39)$ of the response followed by those who have been in operation for between 3 and 5 years, represented by 31.4 percent of the population $(\mathrm{N}=32)$. The owner-managers are, in most cases, the respondents, as shown by over 70 percent of responses $(\mathrm{N}=72)$. Retailers sell variety of products, however, majority of them sell grocery (66.7 percent, $\mathrm{N}=68$ ) followed by those selling clothes $(11.8, \mathrm{~N}=12)$ percent.

Retailers make use of computers as shown by 75.5 percent $(\mathrm{N}=77)$ who said they computers. It seems also that the respondents are mainly black South African (66.7 percent, $\mathrm{N}=68$ ) which can be attributed to the fact that majority of black SA reside in Soweto.

Most of the retailers are small businesses generating sales revenue of between R100 000 and R400 000 (35.3 percent, $\mathrm{N}=36$ ) followed by those generating less than R100 000 sales per year (28.4 percent, $\mathrm{N}=22$ ). The third group of independent retailers generate sales of between R400 001 and R900 000 as shown by 21.6 percent of the population. 


\section{Findings}

From Table 1 below, it can be observed that independent retailers face some major challenges. The 10 most serious challenges they experience are:

- Competition from other businesses (87\%). Costs on buying products are too high $(83 \%)$.
- High inventory costs (78\%).

- High rental costs (77\%).

- High taxation (70\%).

- Lack of business skills (70\%).

- Inability to market the products (63\%).

- Government regulations (63\%).

- Difficulty findings suitable location (60\%).

Table 1. Descriptive: frequencies and percentages

\begin{tabular}{|l|c|c|c|c|c|}
\hline \multicolumn{1}{|c|}{ Variable description } & $\mathrm{N}$ & \multicolumn{2}{c|}{ Prequency } & $\mathrm{N}$ & $\mathrm{N}$ \\
\hline & & $\mathrm{Y}$ & $\mathrm{N}$ & 24.5 \\
\hline High business rental costs & 102 & 77 & 25 & 75.5 & 41.2 \\
\hline Difficulty finding suitable location for the business & 102 & 60 & 42 & 58.8 & 45.1 \\
\hline Unavailability of affordable suppliers & 102 & 56 & 46 & 54.9 & 34.3 \\
\hline High costs of transportation & 102 & 67 & 35 & 65.7 & 55.9 \\
\hline Late deliveries & 102 & 45 & 57 & 44.1 & 59.8 \\
\hline Uncertain availability of stock from suppliers & 102 & 41 & 61 & 40.2 & 23.5 \\
\hline High inventory costs & 102 & 78 & 24 & 76.5 & 38.2 \\
\hline Government regulations & 102 & 63 & 39 & 38.2 & 14.7 \\
\hline Competition from other businesses & 102 & 87 & 15 & 85.3 & 44.1 \\
\hline Lack of guidance on business development & 102 & 57 & 45 & 55.9 & 33.3 \\
\hline Limited access to finance & 102 & 68 & 34 & 66.7 & 54.9 \\
\hline Shortage of skills & 102 & 46 & 56 & 45.1 & 58.8 \\
\hline Shortage of suppliers & 102 & 42 & 60 & 41.2 & 65.7 \\
\hline Suppliers are unreliable & 102 & 35 & 67 & 34.3 & 18.6 \\
\hline Costs of buying the products are too high & 102 & 83 & 19 & 81.4 & 43.1 \\
\hline Lack of market access & 102 & 58 & 44 & 56.9 & 31.4 \\
\hline High taxation & 102 & 70 & 32 & 68.6 & 54.9 \\
\hline Lack of business skills & 102 & 45 & 57 & 44.1 & 42.2 \\
\hline Inability to market our products effectively & 102 & 59 & 43 & 57.8 & 50 \\
\hline Poor sales performance & 102 & 51 & 51 & 50 & 51.8 \\
\hline Lack of market research/ forecasting & 102 & 63 & 39 & 52 & 38.2 \\
\hline Poor knowledge of market competition & 102 & 53 & 49 & 52 & 48 \\
\hline Selling the product & 102 & 56 & 46 & 54.9 & 45.1 \\
\hline
\end{tabular}

It is clear from the above list that independent retailers suffer competition from other businesses, as shown by $87 \%$ of the responses. This could be that major retailers are making strides in previously disadvantaged areas such as in the townships, periurban and rural areas. Other than competition from major retailers, SA business owners also face competition from foreign owned businesses that have also entered township and city centre with less expensive and quality products. The $2^{\text {nd }}$ most serious challenge is the costs of buying the products. As reported in the demographic section, majority of independent retailers buy from wholesalers. This means that they are unable to buy products directly from manufacturers, where they could possibly buy products at lower prices depending on quantity of purchase. The SA owned independent retailers also suffer from their inability to join hands together as a cooperative where they could buy goods together. Some of them do not join existing cooperatives or agents that could buy products on their behalf. This could be the reason why the costs of buying are high, since they buy few products at a time and are unable to negotiate quantity discount from their suppliers.

Factors such as high inventory costs and high rental also pose challenges to independent retailers. Retailers keep stock they purchase from suppliers to ensure that they have products available when consumers need them. This requires that they have sufficient space to keep the stock. The larger the space, the higher the costs of keeping inventory which might impact on their profitability. High rental costs are a major factor for all small businesses. Unlike major retailers that can afford to locate their branches in major shopping centres, small businesses cannot afford that. This might result in independent retailers selecting areas that are less expensive that might not be good location for them to reach their customers. It might also lead them into making less profit due to high rental costs.

Unfortunately, all businesses need to pay taxation. However, for small businesses, this poses as a challenge. More important is the fact that 
independent retailers lack business skills, which is important for them to succeed especially against major competitors who are entering their areas. It appears that inability to market the products, government regulations and difficulties finding a suitable location are moderate challenges. This could mean that location is available except that rental costs are too high.

This study confirms that marketing pose as a major challenge for independent retailers, due to competition from other businesses scoring $87 \%$, which is a marketing related challenge. The $2^{\text {nd }}$ challenge was identified as finance, due to costs of buying, costs of inventory and rental costs scoring higher than other challenges. This is contrary to findings by Olwawale and Gware (2010) who found that finance is the most challenging factor followed by marketing. However, Bowen, Morara \& Nureith (2009) found that competition to be the main challenge, supporting findings of this study.
Furthermore, Lekhanya (2010) found both finance and competition to be the main challenges from small businesses which shows that challenges faced by small businesses may differ for types of businesses and location of the businesses.

Finance related challenges. The finance related costs, as shown in Figure 1. The most challenging factors for independent retailers are costs of buying the products, high inventory costs and high rental costs which are among the 10 most challenging factors for independent retailers. Limited access to finance does not seem to pose a major challenge which contract existing findings that listed lack of access to finance as a major challenge restricting small business growth (Ladzani \& Netswera, 2009; Beck \& Demirguc-Kunt, 2006). Olawale \& Garwe (2010) found transpiration costs to be the $14^{\text {th }}$ obstacle affecting small business growth which support these findings that transportation costs are not a major challenge for independent retailers.

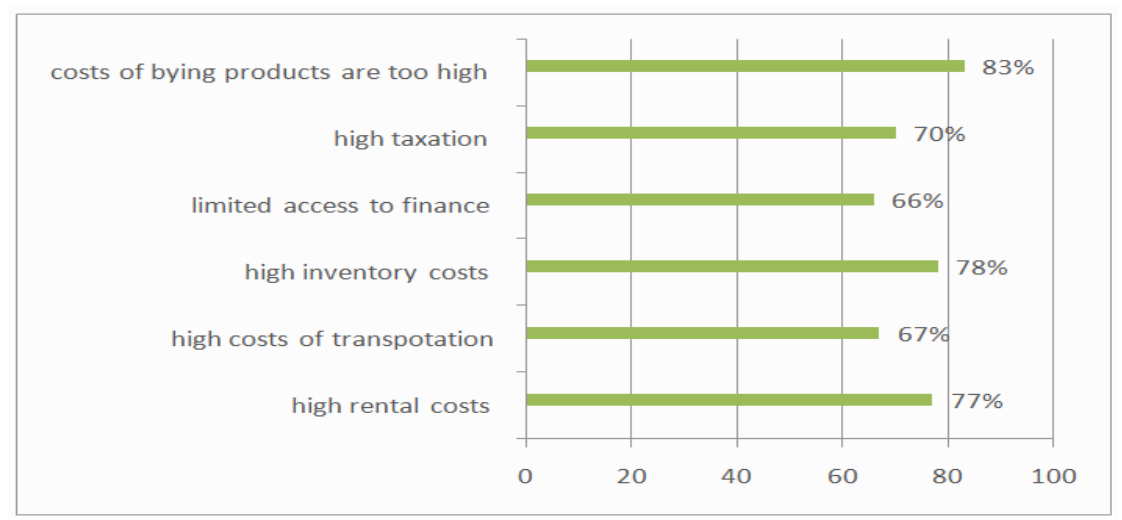

Marketing related challenges. With regard to marketing related factors, competition from other businesses is the most pressing factor for independent retailers, which also appeared among the 10 major challenges for retailers. Other marketing related factors affecting independent retailers are 'inability to market the products effectively', poor sales performance, lack of market access and lack of guidance on business development. Figure 2 shows marketing related factors affecting independent retailers. Van Scheers (2011) also found marketing to be a major challenge for small businesses with competition from other businesses being the number challenge small businesses face. Therefore, these findings support those of existing studies.

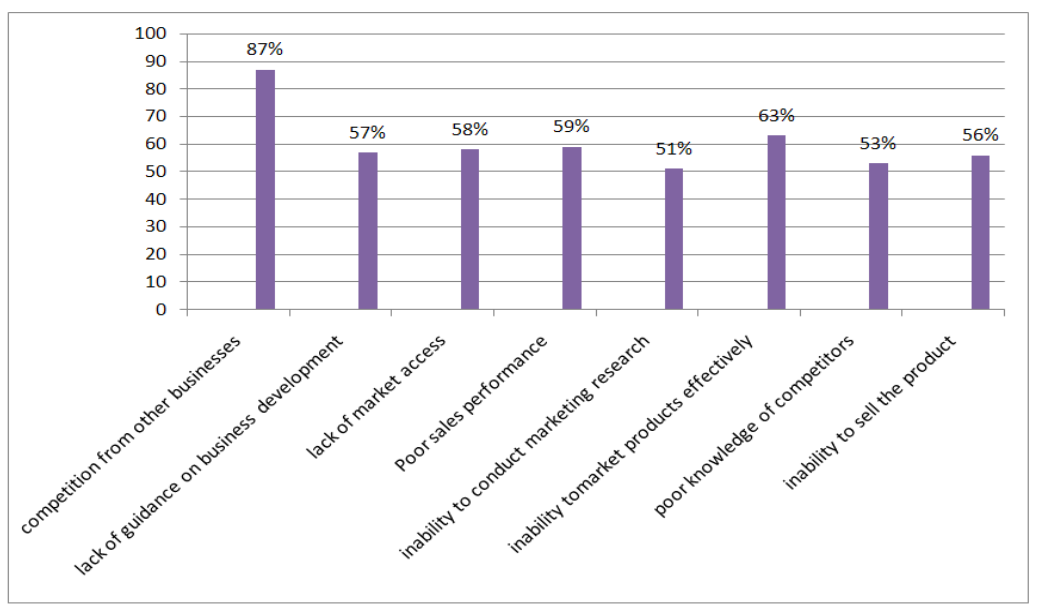

Fig. 2. Marketing related challenges 
Supplier related factors. It seems that independent retailers do face not major challenges related to their suppliers, as can be seen in Figure 3. For example, unavailability of affordable suppliers was rated by $56 \%$ of respondents which shows that this is not a major challenge for independent retailers. Other supplier related factors were also rated lower.

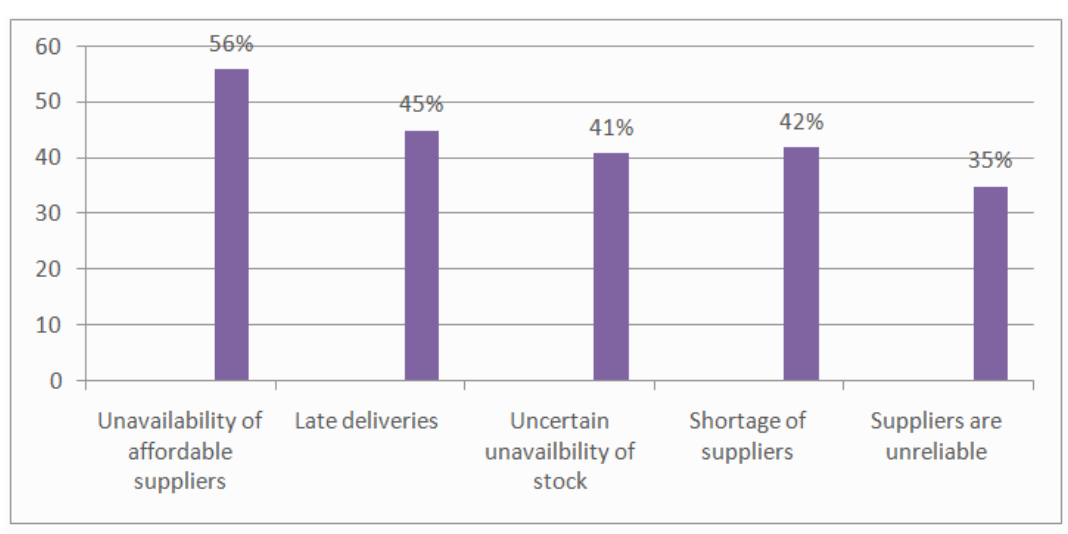

Fig. 3. Supplier related challenges

Business related factors. Independent retailers believe that they do not possess the business skills required for them to be successful in their businesses, as rated by $70 \%$ of the respondents. This supported existing findings that SMEs lack businesses skills which impact on their performance (Blignaut \& Demana, 2002). Government regulations and difficulty finding suitable location also appeared among the 10 most serious challenges; however, they are moderate challenges. This is shown in Figure 4 below.

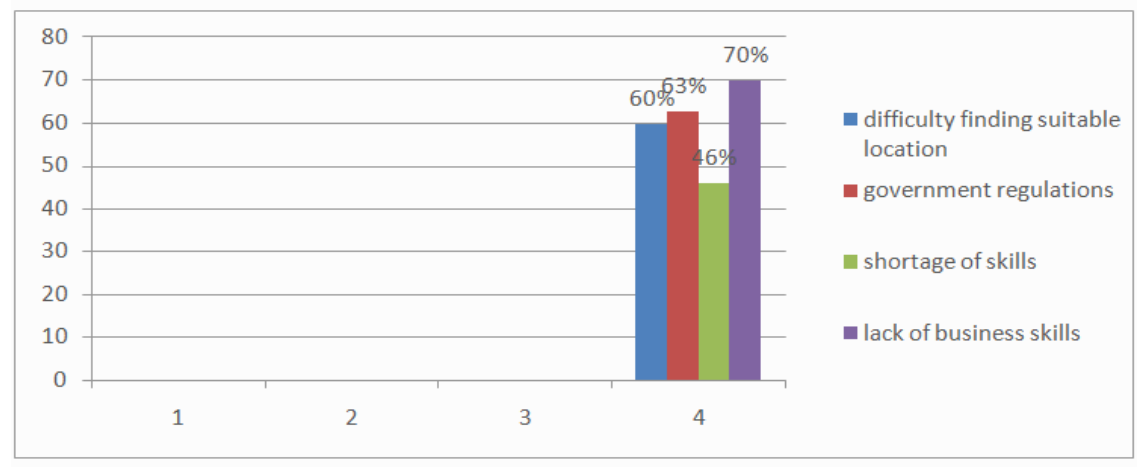

Fig. 4. Business related challenges

\section{Recommendations}

Since competition was cited as the main challenge facing independent retailers, they could identify strategies their competitors are using and better their position against competitors. Independent retailers must improve their marketing effort. Since the costs of keeping inventory and costs of buying were also cited as some of the major challenges, independent retailers could reduce these challenges by joining cooperatives that serve small independent retailers. These cooperatives could be useful for them since they buy on behalf of their members which could lead to reduced costs of buying. Some of the cooperatives keep stock on their warehouses which means that independent retailers could keep enough for them to sustain their businesses, thus, leading to reduced inventory costs.

It is essential that different forms of support interventions be developed and targeted at independent retailers. Although there is existing support programs targeted at small businesses,
Rogerson (2004) found that existing government SMME programs are largely biased towards the groups of small and medium-sized enterprises and, to a large extent, have bypassed microenterprises and the informal economy. Ladzani and Netswera (2009) also support that small businesses do not receive necessary support available from government. Therefore, there is a need for government and its agencies to communicate all the necessary support available to small businesses, including independent retailers, so that they can access them.

There is also a need for independent retailers to attended training programs available, especially those related to finance, marketing and business management. There is a need for these retailers to acquire business related skills for them to compete successfully in the market. Existing studies have reported that existing training programs are also inaccessible to some of the businesses (Makhitha \& Bresler, 2011). It is also important that these raining 
programs are made accessible to all small businesses, including the independent retailers. Owner-managers of these independent retailers also need to take steps to find out about the existing programs and attend the training, so that they can acquire business and other skills needed to run their businesses successfully.

Government conducted an investigation on the impact of large retailers' expansion strategies to independent retailers, which shows that government is concerned about the growth and survival of independent retailers. The findings of this investigation could be used to formulate strategies that can be put in place to support and protect the independent retailers.

\section{Conclusion}

Independent retailers face a number of challenges. This study has identified the 10 most pressing challenges for independent retailers. The study also grouped challenges to determine if they are finance related, marketing related, supplier related and business related. Among the 10 most challenging factors for retailers, the study identified competition from other businesses (87\%), costs on buying products are too high $(83 \%)$, high inventory costs (78\%), high rental costs (77\%) and high taxation $(70 \%)$ as the five most pressing challenges. It is important that independent retailers find ways to deal with these challenges. It is also important for policy makers to find ways in which these challenges may be reduced, if not eliminated, for independent retailers to perform successfully.

This study focused on independent retailers in Johannesburg and Soweto. The study also used convenience sampling method targeting mainly independent retailers from Soweto. Other studies could investigate these factors across other provinces to determine if the challenges apply to retailers in other provinces. Further studies could also investigate these challenges among SMEs other than independent retailers.

\section{References}

1. Abbad, H. \& Paché, G. (2013). The impact of logistical criteria in the selection of SMEs by large food retailers - a case study in an emerging country, Problems and Perspectives in Management, Volume 11, Issue 1, pp. 23-33.

2. Agarwal, P., Sahla, M., Mishara, V., Bag, M. \& Singh, V. (2011). A review of multi-criteria decision making techniques for supplier evaluation and selection, International Journal of Industrial Engineering Computations, 2(4), pp. 801-810.

3. Basker, E. and Noel, M. (2013). Competition Challenges in the Supermarket Sector with an Application to Latin American Markets. Report for the World Bank and the Regional Competition Centre for Latin America.

4. Beck, T \& Demirguc-Kunt, A. (2006). Small and medium-size enterprises: Access to finance as a growth constraint, Journal of Banking \& Finance, 30, pp. 2931-2943.

5. Bowen, M., Morara, M. \& Mureithi, S. (2009). Management of business challenges among Small and micro enterprises in Nairobi-Kenya, KCA Journal of Business Management, Vol. 2.

6. Brink, A. \& Cant, M. (2009). Problems experienced by small businesses in South Africa.

7. Bhutta, S.K. \& Huq, F. (2002). Supplier selection problem: A comparison of the total cost of ownership and analytic hierarchy process approaches, Supply Chain Management: An International Journal, 7(3), pp. 26-135.

8. Chiliya, N, Herbst, G. \& Roberts-Lombard, M. (2009). The impact of marketing strategies on profitability of small grocery shops in South African townships, African Journal of business Management, 3 (3), pp. 70-79.

9. Chikweche, T. (2015). Independent Retail and Grocery Shops in Zimbabwe: Survival and Demise in a Crisis and Post-Crisis Era, Journal of Marketing Channels, 22, pp. 121-136.

10. das Nair, \& Chisoro, S. (2015). The expansion of regional supermarket chains: Changing models of retailing and the implications for local supplier capabilities in South Africa, Botswana, Zambia, and Zimbabwe. United Nations University world Institute for development Economics Research.WIDER Working Paper 2015/114.

11. das Nair, R. and Dube, S.S. (2015). Competition and regulation: competition, barriers to entry and inclusive growth: case study on fruit and veg city. Centre for competition, regulation and economic development, university of Johannesburg. Working paper 9/2015.

12. Department of Economic Development. 2015. 3 Grocery retail sector market inquiry terms of reference, October 2015. Report No. No. 39347.

13. Durham, L. (2011). Opportunities and challenges for South African retailers, Supermarket \& Retailer, pp. 33-35.

14. Ebrahimpour, M. \& Johnson, J.L. (1992). Quality, vendor evaluation and organizational performance: A comparison of US and Japanese ${ }^{R} \mathrm{rms}$, Journal of Business Research, 25 (2), pp. 129-142.

15. Fernridge and Bank of America Merril Lynch. 2011. SA Consumer Story - Not Spent Yet, Bank Of America Merril Lynch, June 2011.

16. Hassan, M.U., Qureshi, S.U., Sharif, S. \& Mukhtar, A. (2013). Impact of Marketing Strategy Creativity on Organizational Performance via Marketing Strategy Implementation Effectiveness: Empirical Evidence from Pakistani Organizations, Middle-East Journal of Scientific Research, 16 (2), pp. 264-273.

17. Hogarth-Scott, S., Watson, K., \& Wilson, N. (1996). Do small businesses have to practice marketing to survive and grow? Marketing Intelligence \& Planning, Vol. 14, No. 1, pp. 6-18. 
18. Kannan, V.R. \& Keah Choon Tan, K.C. (2003). Attitudes of US and European managers to supplier selection and assessment and implications for business performance, Benchmarking: An International Journal, 10(5), pp. 472-489.

19. Kongolo, M. (2010). Job creation versus job shedding and the role of SMEs in economic development, African Journal of Business management, 4 (11), pp. 2288-2295.

20. Ladzani, W. \& Netswera, G. (2009). Support for rural smallbusinesses in Limpopo Province, South Africa, Development Southern Africa, 26(2), pp. 225-239.

21. Leenders, M.R., Johnson, P.F., Flynn, A.E. \& Fearon, H.E. (2006). Purchasing and supply management. 13th edition. Boston: McGraw-Hill.

22. Lekhanya, L.M. (2010). The Use of Marketing Strategies by Small, Medium and Micro Businesses in Rural KwaZulu-Natal. An unpublished PHD dissertation thesis, Durban University of Technology.

23. Liedeman, R., Charman, A., Piper, L. \& Petersen, L. (2013). Why are foreign-run spaza shops more successful? The rapidly changing spaza sector in South Africa. Sustainable Livelihoods Foundation. Econ3x3.

24. Ligthelm, A.A. (2008). The impact of shopping mall development on small township retailers, South African Journal of Economic and Management Sciences, 11(1), pp. 37-53.

25. Lussier, R.N \& Hyder, S. (2016). Why businesses succeed or fail: A study on small businesses in Pakistan, Journal of Entrepreneurship in Emerging Economies, Vol. 8, No. 1, pp. 82-100.

26. McCartan-Quinn, D. \& Carson, D. (2002). Issues which impact upon marketing in small firm, Small Business Economics, Vol. 21, No. 2, pp. 201-216.

27. Simpson, M. \& Taylor, N. (2002). The role and relevance of marketing in SMEs: Towards a new model, Journal of Small Business and Business Development, 9(4), pp. 370-382.

28. Migiro, A \& Ocholla, D.N. (2005). Information and communication technologies in small and medium scale tourism enterprises in Durban, South Africa, Information Development, 21(4), pp. 283-294.

29. Muhammed, M.Z., Char, A.K., Yasoa, M.R \& Hassan, Z. (2010). Small and Medium Businesses (SMEs) Competing in the Global Business Environment: A Case of Malaysia, International Business Research, 3(1), pp. 66-75.

30. Naude, M.J. (2014). A perspective on the criteria used by SMEs in Pietermaritzburg to select suppliers, Journal of Contemporary Management, Volume 10, pp. 1-19.

31. Nieman, G., Hough, J. \& Nieuwenhuizen, C. (2003). Entrepreneurship: A South Africa perspective. Pretoria: Van Schaik.

32. Olawale, F. \& Garwe, D. (2010). Obstacles to the growth of new SMEs in South Africa: A principal component analysis approach, African Journal of Business Management, Vol. 4(5), pp. 729-738.

33. PWC. (2012). South African Retail and Consumer Products Outlook 2012-2016. PWC and Economist Intelligence Unit Report, October 2012. Available at: (http://www.pwc.co.za/en/assets/pdf/retail-and-consumer-productsoutlook-2012-2016.pdf (accessed on 15 July 2016).

34. Radipere, S. \& Van Scheers, L. (2005). Investigating whether a lack of marketing and managerial skills is the main cause of business failure in South Africa, South African Journal of Economics and Management Sciences, 8 (4), p. 402.

35. Rogerson, C.M. (2004). The impact of the South Africangovernment's SMME programmes: A ten-year review (1994-2003). Development Southern Africa, Vol. 21, No. 5, December 2004.

36. Rogerson, C.M. (2001). Growing the SMME manufacturing economy in South Africa: evidence from Gauteng province, Journal of Contemporary Management, 19(2), pp. 267-291.

37. Simpson, M. \& Taylor, N. (2002). The role and relevance of marketing in SMEs: Towards a new model, Journal of Small Business and Business Development, 9(4), pp. 370-382.

38. Standard Bank. (2014). 5-key-trends-affecting-the-retail-market-in-2014. Accessed from http://bizconnect. standardbank.co.za/sector-news/retail-wholesale/south-africa-5-key-trends-affecting-the-retail-market-in-2014.aspx, accessed on 01/07/2016.

39. Sustinalytics. (2012). Building a Sustainable South African Food Retail Sector, Issues for Responsible Investors, August.

40. Thomas White. (2011). Emerging Market Spotlight Retail in South Africa: Making an Impression.

41. W\&R Seta. (2011). Independent Food Retailers in the Republic of South Africa. Can they Ensure Sustainability in an Evolving Retail Landscape?

42. Van Scheers, L. (2011). SMEs' marketing skills challenges in South Africa, African Journal of Business management, Vol. 5, No.13, pp. 5048-5056. 